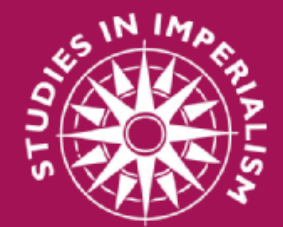 \\ IMPERIAL GITIES
}

\section{LANDSCAPE, DISPLAY AND IDENTITY}

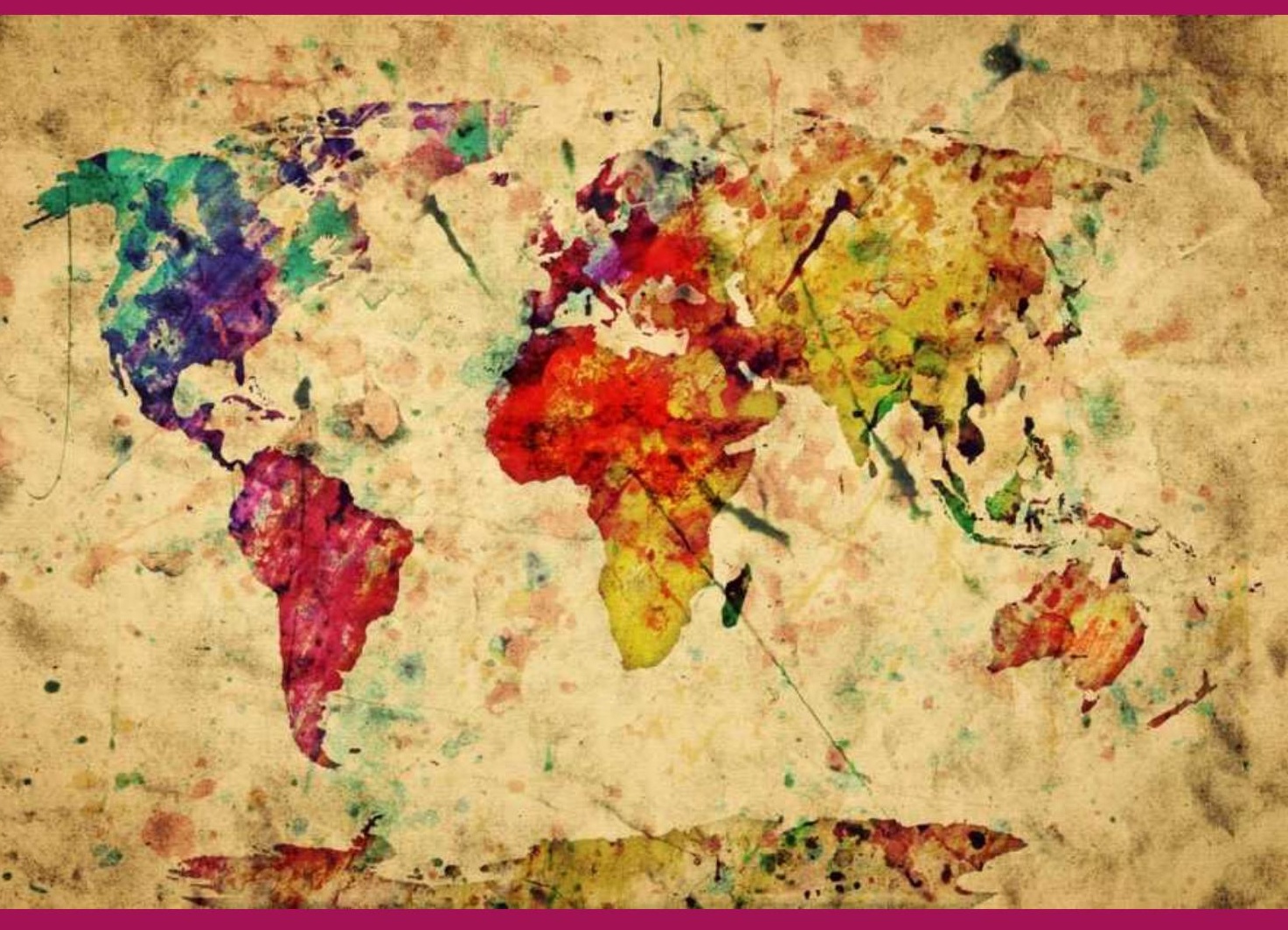

EDITED BY FELIX DRIVER AND DAVID GILBERT 


\section{IMPERIALISM}

general editor John M. MacKenzie

Established in the belief that imperialism as a cultural phenomenon had as significant an effect on the dominant as on the subordinate societies, Studies in Imperialism seeks to develop the new socio-cultural approach which has emerged through cross-disciplinary work on popular culture, media studies, art history, the study of education and religion, sports history and children's literature. The cultural emphasis embraces studies of migration and race, while the older political and constitutional, economic and military concerns will never be far away.

It incorporates comparative work on European and American empire-building, with the chronological focus primarily, though not exclusively, on the nineteenth and twentieth centuries, when these cultural exchanges were most powerfully at work.

\section{Imperial cities}

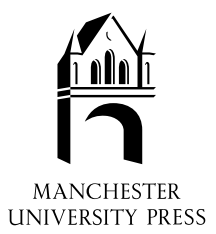




\title{
AVAILABLE IN THE SERIES
}

\author{
Britain in China \\ Community, culture and colonialism, 1900-1949 Robert Bickers \\ New frontiers \\ Imperialism's new communities in East Asia 1842-1952 \\ eds Robert Bickers and Christian Henriot \\ Western medicine as contested knowledge \\ eds Andrew Cunningham and Bridie Andrews
}

The Arctic in the British imagination 1818-1914 Robert G. David

$$
\text { Imperial cities }
$$

Landscape, display and identity

eds Felix Driver and David Gilbert

Science and society in Southern Africa Saul Dubow

Equal subjects, unequal rights

Indigenous peoples in British settler colonies, 1830s-1910

Julie Evans, Patricia Grimshaw, David Phillips and Shurlee Swain Unfit for heroes

Reconstruction and soldier settlement in the Empire between the wars Kent Fedorowich

Emigration from Scotland between the wars Opportunity or exile? Marjory Harper

Empire and sexuality

The British experience Ronald Hyam 'An Irish Empire?'

Aspects of Ireland and the British Empire ed. Keith Jeffery Reporting the Raj

The Britsh press in India, c. 1880-1922 Chandrika Kaul

Law, history, colonialism

The reach of empire eds Diane Kirkby and Catherine Coleborne

The South African War reappraised Donal Lowry

The empire of nature

Hunting, conservation and British imperialism John M. MacKenzie

Imperialism and popular culture ed. John M. MacKenzie

Propaganda and empire

The manipulation of British public opinion, 1880-1960 John M. MacKenzie

Gender and imperialism ed. Clare Midgley

Guardians of empire

The armed forces of the colonial powers, c. 1700-1964

eds David Omissi and David Killingray

Female imperialism and national identity

Imperial Order Daughters of the Empire Katie Pickles

Married to the empire

Gender, politics and imperialism in India, 1883-1947 Mary A. Procida

Imperial persuaders

Images of Africa and Asia in British advertising Anandi Ramamurthy

Imperialism and music

Britain 1876-1953 Jeffrey Richards

Colonial frontiers

Indigenous-European encounters in settler societies ed. Lynette Russell

West Indian intellectuals in Britain ed. Bill Schwarz

Colonial masculinity

The 'manly Englishman' and the 'effeminate Bengali' Mrinalini Sinha

Iute and empire

The Calcutta jute wallahs and the landscapes of empire

Gordon T. Stewart

The imperial game

Cricket, culture and society

eds Brian Stoddart and Keith A. P. Sandiford

The French Empire at war, 1940-45 Martin Thomas

British culture and the end of empire ed. Stuart Ward

Travellers in Africa

British travelogues, 1850-1900 Tim Youngs 


\title{
Imperial cities
}

LAN D S CAPE, DIS PLAY

AND IDENTITY

\author{
edited by Felix Driver \\ and David Gilbert
}

\author{
MANCHESTER \\ UNIVERSITY PRESS \\ Manchester and New York
}

distributed exclusively in the USA by PALGRAVE 
While copyright in the volume as a whole is vested in Manchester University Press, copyright in individual chapters belongs to their respective authors, and no chapter may be reproduced wholly or in part without the express permission in writing of both author and publisher.

Published by MANCHESTER UNIVERSITY PRESS

OXFORD ROAD, MANCHESTER M13 9NR, UK

and ROOM 400, 175 FIFTH AVENUE, NEW YORK, NY 10010, USA

www.manchesteruniversitypress.co.uk

Distributed exclusively in the USA by

PALGRAVE

175 FIFTH AVENUE, NEW YORK, NY 10010, USA

Distributed exclusively in Canada by

UBC PRESS, UNIVERSITY OF BRITISH COLUMBIA,

2029 WEST MALL, VANCOUVER, BC, CANADA V6T $1 Z 2$

British Library Cataloguing-in-Publication Data

A catalogue record for this book is available from the British Library

Library of Congress Cataloging-in-Publication Data applied for

ISBN 0719054133 hardback

ISBN 071906497 X paperback

First published 1999

First published in paperback 2003

$\begin{array}{llllllll}10 & 09 & 08 & 07 & 06 & 05 & 04 & 03\end{array}$

109876543221

Typeset in Trump Medieval

by Northern Phototypesetting Co Ltd, Bolton 